\title{
Introduction: The Aulikara Power Network
}

As I have noted in the Preface above, this book is not meant to present a new history of the Aulikaras, though it may perhaps be an important foundation stone for one. It is, however, not easy even to define a "history of the Aulikaras." There was no single and uninterrupted line of kings who bore this family name: there is epigraphic evidence for at least two, possibly three such dynasties, which were presumably related through collateral descent and/or intermarriage, yet none of their presently known members provide a direct link to another of these dynasties. Part of their history appears to be closely intertwined with two other potent families who shared in, and contributed to, their power in a subordinate position. Aulikara rule was geographically localised in the northwestern part of present-day Malwa, particularly around the town of Mandsaur (at the time called Daśapura), which was their capital at least from the early fifth century onward. Most of the relevant inscriptions come from the vicinity of this place, with some of the earlier ones originating further east (see Figure 3). This stretch of territory was controlled and contested by various superpowers in the course of time, such as the Sakas before Aulikara days, then the
Guptas, later the Hūnas, possibly the Vākāṭakas and - at the end of the present book's timeframe - the Kalacuris. It is thus impossible to conceptualise "Aulikara history" in isolation.

Richard Salomon $(1989,11-30)$ has given an excellent overview of the internal and external relations of the dynasties concerned, which frees me from the burden of needing to do so here. ${ }^{1}$ A freely available $\mathrm{PhD}$ thesis by Naval Kishore (1999) provides a good review of various opinions offered (especially by Indian scholars) on aspects of Aulikara history. More recently, Elizabeth Cecil (2016, 117-20) has emphasised the importance of investigating Daśapura around the turn of the sixth century in terms of political networks. For the purposes of this book, I define the Aulikara power network or "the Aulikaras and their associates" as members of prominent lineages who occupied positions of power in and around Mandsaur from the early fifth to the late sixth century. Since I am concerned with inscriptions commissioned by or under these rulers and governors, I can conveniently ignore the threads of the network that lead outside this conglomeration, except for briefly taking note of where an inscription indicates such a thread. 
